\title{
8. 熱帯地域におけるフラビウイルス感染症
}

\author{
五十嵐 章 \\ (長崎大学愁带医学研究ウイルス学部門)
}

\section{はじめに}

フラビウイルスは ${ }^{38)}$, その代表である黄熱ウイルスで 示されるように，その多くが蚊やダニといった吸血性 節足動物で媒介されるアルボウイルスとしての伝播様 式を備えており ${ }^{2)}$ ，七トや家畜に病原性を示すものも多 〈含まれている27,34)。発展途上国の多くは熱带地域に存 在しており, 熱带の気候条件は蚊の生育と活動に適し ているので, フラビウイルスの中でも蚊で媒介される ウイルスの感染症が問題となっている。フラビウイル スに属するアルボウイルスの感染に起因する疾患の臨 床症状はさまざまである。最も軽傷の場合はには不明 熱 (Fever of unknown origin=FUO), やや重症にな ると発熱・痛み・発疹を示すデング症候群, 更に重症 になると発熱・出血傾向・循環障害を示しショック死 の可能性がある出血熱, 最も重症な場合には発熱と意 識障害を示し重篤な精神神経障害を伴う後遺症を残す 脳炎を呈する。この総説では, 現在蚊媒介性フラビウ イルス感染症の中でも, 殊に熱带における発展途上国 で問題となっている黄熱，デングウイルス感染症，お よび日本脳炎について, それぞれの疫学的現状と対策 の問題点について述べる。

\section{1. 現状}

野口英世博士で有名な黄熱は, 発熱・出血傾向・黄 㾝を 3 主徴候とするウイルス性出血熱の一つで, 現在 もアフリカ・中南米の熱帯雨林地帯において公衆衛生

Flavivirus infections in tropical areas

Akira Igarashi

Department of Virology, Institut of Tropical Medicine, Nagasaki University, Nagasaki 852

T852 長崎市坂本 1 丁目 12 番 4 号
上の問題を提起している(図 1)。1986-1990年のWHO に報告された黄熱患者数を表 $1 ， 2$ に示している。過 去10年間での黄熱の流行は, 南米ではボリビア, ブラ ジ, コロンビア, エクアドル, 仏領ギアナ, ペルー に限られ，ボリビア，ブラジル，ペルーの 3 力国で毎 年黄熱患者と死亡者が発生しているのに対して,アフ リカでは12力国で患者が発生しており，年と共にその 流行の中心地域が移動している。すなわち1983年前後 では流行の中心はブルキナ・ファソとガーナであった が, 1986年以後はナイジェリアの流行が問題となって いる。十イジェリアの流行が大きかった結果, 1988, 1989, 1990年 3 力年の患者数（死亡者数）はそれぞれ $2,085(709), 3,497(800), 4,344$ (416) 名で, 致命率で は $83 \% ， 23 \% ， 10 \%$ となった。

1989-1990の 5 年間における世界の黄熱患者の総数 は17,728名 (死亡者紷数 4,710 名) となり, WHOの記 録では 1948 以来の 5 年間当たり黄熱が最も流行した期 間となった。その内訳では,アフリカでは患者総数 16,782 名 (死亡者数 791 名), 南米では患者総数946名 (死亡者 数791名)で，いずれも1948年以来の 5 年間当たりの最 高の記録である。

アフリカにおける黄熱の流行は1989年にはナイジェ リアに限局していたが，1990年には周辺諸国のニジェ ールとカメルーンでも流行した。1986-1990年の 5 年 間においてナイジェリアの22州中19州で黄熱が流行し た。1986年 9 月, ナイジェリア東南部から始まった流 行は次第に西部，北部，東北部へと拡大し，12月には 南部にも侵入した。このような黄熱流行の伝播経路は, 乾季を南部で過ごし雨季には北部に移動する遊牧民の 移動経路と一致している。遊牧民との関係が推測され る新たな黄熱流行の中心が1987年 8 月にナイジェリア の北西部に出現し1988年の初頭まで流行が持続した。 1988年 3 月から 5 月まではナイジェリアで黄熱患者は 
衰 1 アフリカにおける黄热患者数（死亡者数）の年次変動

\begin{tabular}{|c|c|c|c|c|c|c|c|c|c|c|c|c|}
\hline 年 & アンゴラ & ブルキナ・ファリ & カメルーン & ガーナ & 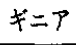 & 象牙海岸 & จリ & モリタニア & ニシ்ェール & ナイジェリア & セネガル & トーゴ \\
\hline 1981 & & & & 4 (1) & & & & & & & $3(1)$ & \\
\hline 1982 & & & & $6 \quad(4)$ & & $25(25)$ & & & & & & \\
\hline 1983 & & $356(286)$ & & $372(201)$ & & & & & & & & \\
\hline 1984 & & $17(16)$ & 17 (16) & & & & & & & $12 \quad$ (1) & & $1(0)$ \\
\hline 1985 & & $7 \quad(3)$ & $7 \quad(3)$ & & & & & & & $(0)$ & & \\
\hline 1986 & & & & & & & & & & $3,921 \quad(623)$ & & \\
\hline 1987 & & & & & $5(2)$ & & $305(145)$ & 21(1) & & $1,726 \quad(744)$ & & $6(0)$ \\
\hline 1988 & & & & & & & & & & $4,920(1,502)$ & & \\
\hline 1989 & $37(14)$ & & & & & & & & & $3,270 \quad(618)$ & & \\
\hline 1990 & & & $173(118)$ & & & & & & $6(6)$ & $4,075 \quad(223)$ & & \\
\hline
\end{tabular}

文献 $39,40,41,42,43)$ 上り改変

衰 2 南米における黄熱患者数（死亡者数）の年次変動

\begin{tabular}{crrrcrc}
\hline 年 & ボリビア & \multicolumn{1}{c}{ ブラジル } & コロンビア & エクアドル & 仏領ギアナ & ペルー \\
\hline 1981 & $102(29)$ & $22(21)$ & $7(7)$ & $2(0)$ & & $98(47)$ \\
1982 & $95(35)$ & $24(24)$ & $2(2)$ & & $19(19)$ \\
1983 & $11(9)$ & $6(6)$ & $1(1)$ & $5(1)$ & $27(26)$ \\
1984 & $5(5)$ & $45(28)$ & $16(15)$ & $1(1)$ & $28(18)$ \\
1985 & $53(37)$ & $7(5)$ & $5(5)$ & $1(0)$ & $59(44)$ \\
1986 & $26(19)$ & $9(8)$ & $6(6)$ & & $118(98)$ \\
1987 & $23(18)$ & $16(14)$ & $17(9)$ & & & $179(170)$ \\
1988 & $12(11)$ & $21(14)$ & $7(7)$ & & & $195(166)$ \\
1989 & $98(79)$ & $9(3)$ & & & $120(100)$ \\
1990 & $50(39)$ & $2(1)$ & $6(6)$ & & $1(0)$ & $17(17)$ \\
\hline
\end{tabular}

文献 $39,40,41,42,43)$ より改変

発生しなかったが，6月上旬には再び流行が始まって いる。1986-1990年の 5 年間ではナイジェリアの黄熱 患者総数は 16,230 名 (死亡者総数 3,166 名), 致命率 11 \%となるが, 保健省とWHO は実際の患者数は報告さ れた患者数の 4-90倍と推測している。Oyo 州での調 查によると，患者の71\%は小児であり，年龄別人口構 成に比較して小児の羅患率が異常に高く，致命率も 10 歳以下の小児が $80 \%$ と高いことを示している。

このような黄熱の流行に对する緊急对策として19861989年に17Dワクチンの接種が行われたが, 流行拡大 の速度には对応できず, ワクチン接種をしていない地 域が突破口となって流行が拡大する結果となった。こ のような現実に対してナイジェリア政府は黄熱ワクチ ン接種を小児の国家ワクチン接種計画に組み入れるこ ととした。この間, 患者の報告制度は改善されたが, ウイルス学的診断, および媒介蚊防除対策は改善され ていない。ナイジェリアの黄熱に関しては, ウイルス の生態学を更に解明する必要がある。

南米では1989に黄熱患者数227名, 死亡者数182名(致
命率 $80 \%$ ）を記録し，1987年以降 3 年間の患者数が 200 名以上を記録し,死亡者数も 4 年連続 100 名を突破した が，1990年には患者数·死亡者数共に100名以下に低下 した。1989年の患者数 (死亡者数) ではペルーが120名 （100名）で最大であったが，ボリビアの98名（79名） も注目に值する。ボリビアでは熱带の Carrasco 県と互 熱帯雨林の Cochabamba で黄熱が流行したが, 1988年 12月この地域に新しい道路が開通した結果移住労働者・ 入植者に患者が発生したので, ボリビア政府はこの地 域において緊急にワクチン接種を行った。1990年にも ボリビアで前年と同じ地域に黄熱が流行し，患者数50 名, 死亡者数 31 を記録したが, 年齢・性別が報告され た例の集計では $62 \% か ゙ 15$ 歳以上の男子であった。

\section{2. 対策}

周知のように南米ではネッタイシマカ撲㓕作戦の結 果, 都市型黄熱は消隇し森林型黄熱の形で残存してい ると考えられてきた。しかしながら近年，南米におい てデングウイルス感染症が流行するようになっており， 


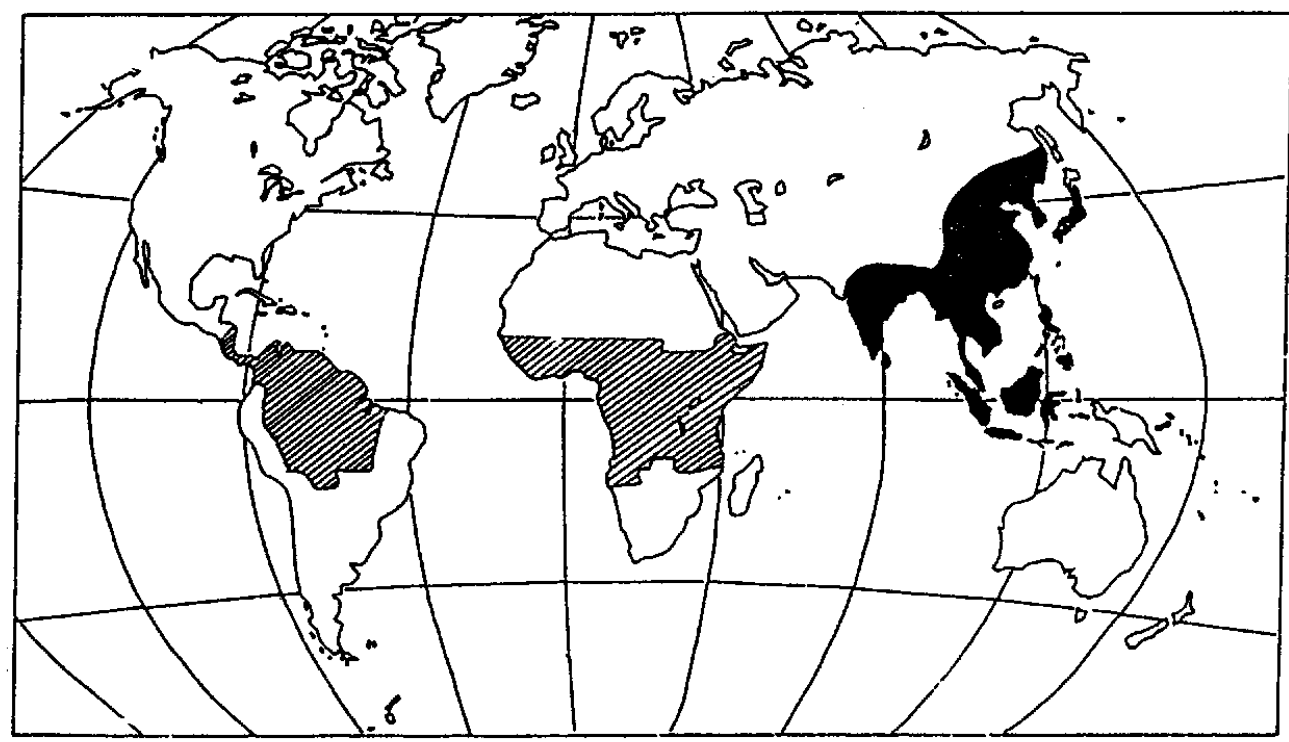

図1．日本脳炎斿よび黄熱の地理的分布

日本脳炎 (JE) は黒色、黄熱 (YF) は斜線が分布地域

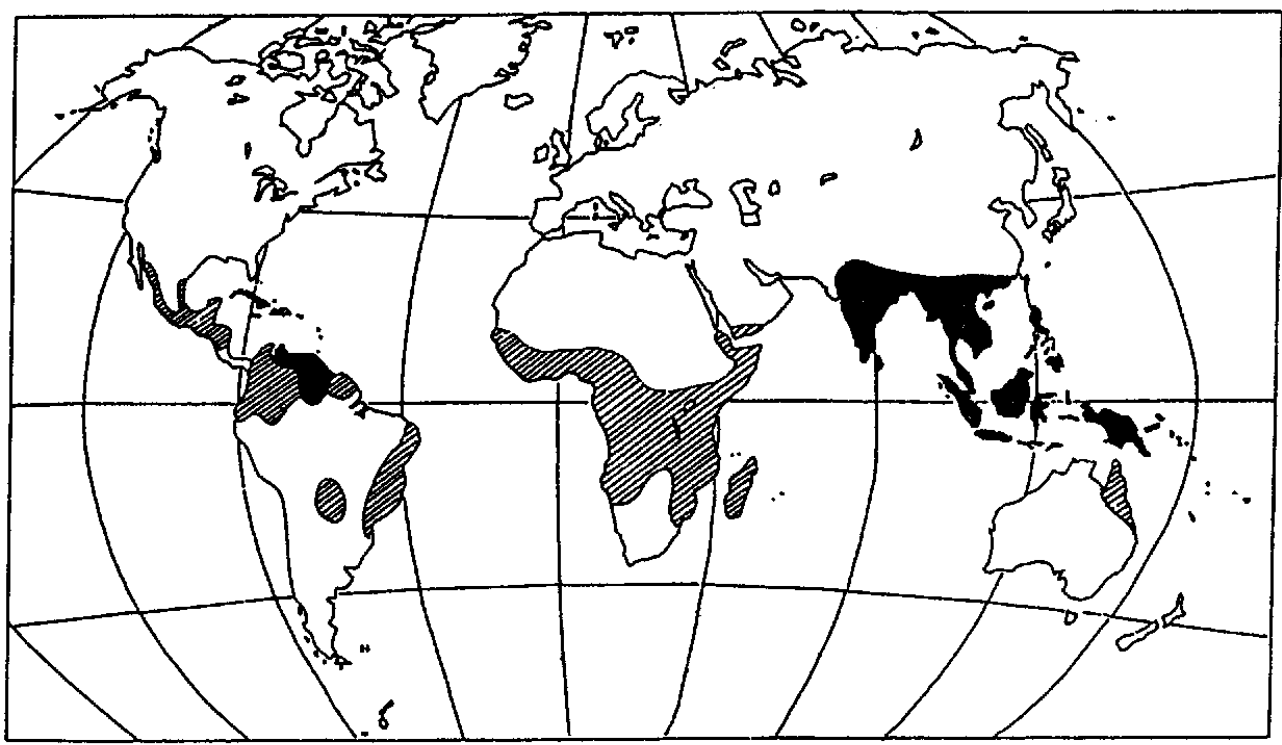

図2.デングウイルス感染症の地理的分布

デング出血熱 (DHF) は黒色、デング熱 (DF) は斜線が分布地域

その媒介蚊はかっての都市型黄熱の媒介蚊と同じネッ タイシマカである。したがって黄熱ウイルスが，現在 都市群で流行している。デングウイルスの伝播サイク ルに導入されれば，かって世界の脅威であった都市型 黄熱が再来する恐れがある。このような可能性を事前
に察知するために，黄熱患者の年齢・性別を追跡調查 する必要がある。近年，南米での黄熱患者は主に成人 男子の森林労働者であることは, 黄熱ウイルスが森林 型サイクルで伝播されていることを示している。黄熱 ウイルスがネッタイシマカで媒介されるようになれば 
現在の患者の年齢・性別の特徵がなくなるはずである。

アフリカでは黄熱の流行对策として緊急ワクチン接 種を行うことは財政的に困難なので, 黄熱ワクチンを 拡大接種計画 (EPI) の一部に組み入れることが望まし い。過去10年間の患者は主に15歳以下の小児であり, 黄熱ワクチンは麻疹ワクチンと同時に生後 9 カ月で接 種できるので,WHO-EPI 諮問委員会はアフリカにお ける黄熱流行の危険がある33力国に対して黄熱ワクチ ンを国家ワクチン接種計画に組み込むように提言した。 この方法を用いれば黄熱ワクチンの単独接種を行う必 要がなく, 黄熱の流行が切迫した問題となる場合には 9 カ月よりも高年齢の小児にもワクチンを接種すれば よい。UNICEFF はこの提言を支持して黄熱ワクチン を他のEPI ワクチンと同様に購入することに同意して いる。1992年 4 月現在, 上記33か国中の16力国 $(48 \%)$ は黄熱ワクチンを EPIに組み込んでいる。これらの諸 国は黄熱患者数および他のサーベイランス情報と共に， 黄熱ワクチン接種率を他の EPI ワクチンと同様報告す ることになっている。

1938年に開発されて50年になる黄熱ワクチン (17D) は，1 回の接種で中和抗体産生率約 $95 \%$, 持続期間は 接種後 40 年間といわれ, 最も安全なワクチンの一つで あり，1945年以来接種後脳炎と考えられる症例は18例 に過ぎない。このうち小児で見られた 3 例は 4 力月あ るいはそれ以下での接種例なので, WHOは生後 6 力月 での接種を推奨している。

\section{デングウイルス感染症}

\section{1. デング熱 (DF) とデング出血策（DHF）の現況}

デングウイルス感染症は古くから発熱・痛み・発疹 を三主徵候とするデング熱 (Dengue fever $=\mathrm{DF}$ ) とし て知られ，世界中の熱帯地域に常在いたが一般には致 命的な疾患ではなかった。1953年，フィリピンの小児 の間で発熱・出血傾向・ショックを示し適切な治療を 施さないと致命的な病気が流行した。当初フィリピン 出血熱と呼ばれたこの疾患はその後東南アジア諸国の 大都市で相次いで流行し, 患者の未梢血液からデング ウイルスが分離されて以後はデング出血熱 (Dengue hemorrhagic fever=DHF）と呼ばれている ${ }^{16)}$ 。

デングウイルスの主要媒介蚊であるネッタイシマカ は人家の内外にある小型の容器で発生しヒトを好んで 吸血する。一方, ヒトはデングウイルスに最も感受性 の高い脊椎動物宿主であり, 感染後高度のウイルス血 症を呈し，媒介蚊にウイルスを与える増幅動物となる ので，人口が密集している熱帯地城の大都市は，殊に
雨季にはデングウイルスの伝播に最適の条件を備えて いる。デングウイルス感染症は世界の熱帯地域に分布 しているが, 殊に東南アジアとカリブ海沿岸地域がそ の二大中心地であり (図 2), 最近は東南アジアから南 太平洋諸島・中国南部へ, カリブ海沿岸地域から南米 へ流行地域が拡大している。DHF は以前は東南アジア に限局されていたが，1981年のキューバの大流行によ ってその流行には地理的・人種的制約が存在しないこ とが明らかとなった ${ }^{11}$ 。近年, デングウイルス感染症は 世界の熱带地域における大問題となっている。その理 由は, 第一に DHF の出現, 第二に患者数と流行地域の 増加・拡大, 第三に有効な防除手段の欠如である。更 に，デングウイルス感染症は熱帯地城のみならず，日 本を含む温帯地域にとっても弯威である。その理由の 一つは, 熱帯に主張する商社員, 学術調査研究員, 旅 行者など多くの人々が流行地域でデングに感染し, 現 地或は帰国後発病する症例がしばしばある。さらに, 最近世界的問題である地球温暖化の准行によってデン グ媒介蚊の生息地域が拡大すれば現在の温带地域にも デングウイルス感染症が流行する恐れがある。過去に も米国，ギリシャ，日本などでデングウイルス感染症 が流行した記録がある。

デングウイルス感染症の患者数は従来の流行地域で ある東南アジア諸国でも増加傾向を示している(表 3)。 たとえば，ヴェトナムでは1960年代に最初の流行があ ったが，筆者が初めてヴェトナムを訪れた1985年の時 点では14万人以上の患者が発生した 1983 年の流行が最 大の流行であった。しかし1987年にはその 2 倍以上の 35万名以上の患者が発生してこの記録が更新された。 1987年には近隣国のタイでも患者数17万名を越す史上 最大の流行を記録している。一方, DHF の致命率は流 行当初の 1950 年代では $50 \%$ に達していたが, その後 治療法が進歩した結果, 現在では $1 \%$ あるいはそれ以 下にまで低下した。しかしながら患者の絶対数が增加 しているので DF/DHF は東南アジアにおいては依然と して小児の最も重要な入院・死亡原因である。

近年，世界の熱带地域でデングウイルス感染症が増 加・拡大傾向を示している原因は多分に経済発展と関 連していると考えられる。経済発展は人口增加 ${ }^{22)}$ と相互 依存関係にあるが，増加した人口は都市部に移動して 都市化現象（Urbanization）を惹起している。都市化 はデング媒介蚊であるネッタイシマカと感受性宿主で ある七トの増加をもたらし，デングウイルスの感染サ イクル拡大に連なる。一方, 経済発展は交通手段・殊 に航空機・の発達をもたらし,デングウイルスに感染 
衰3WHOに報告されたデング出血㙓（DHF）の患者数（死亡者数）

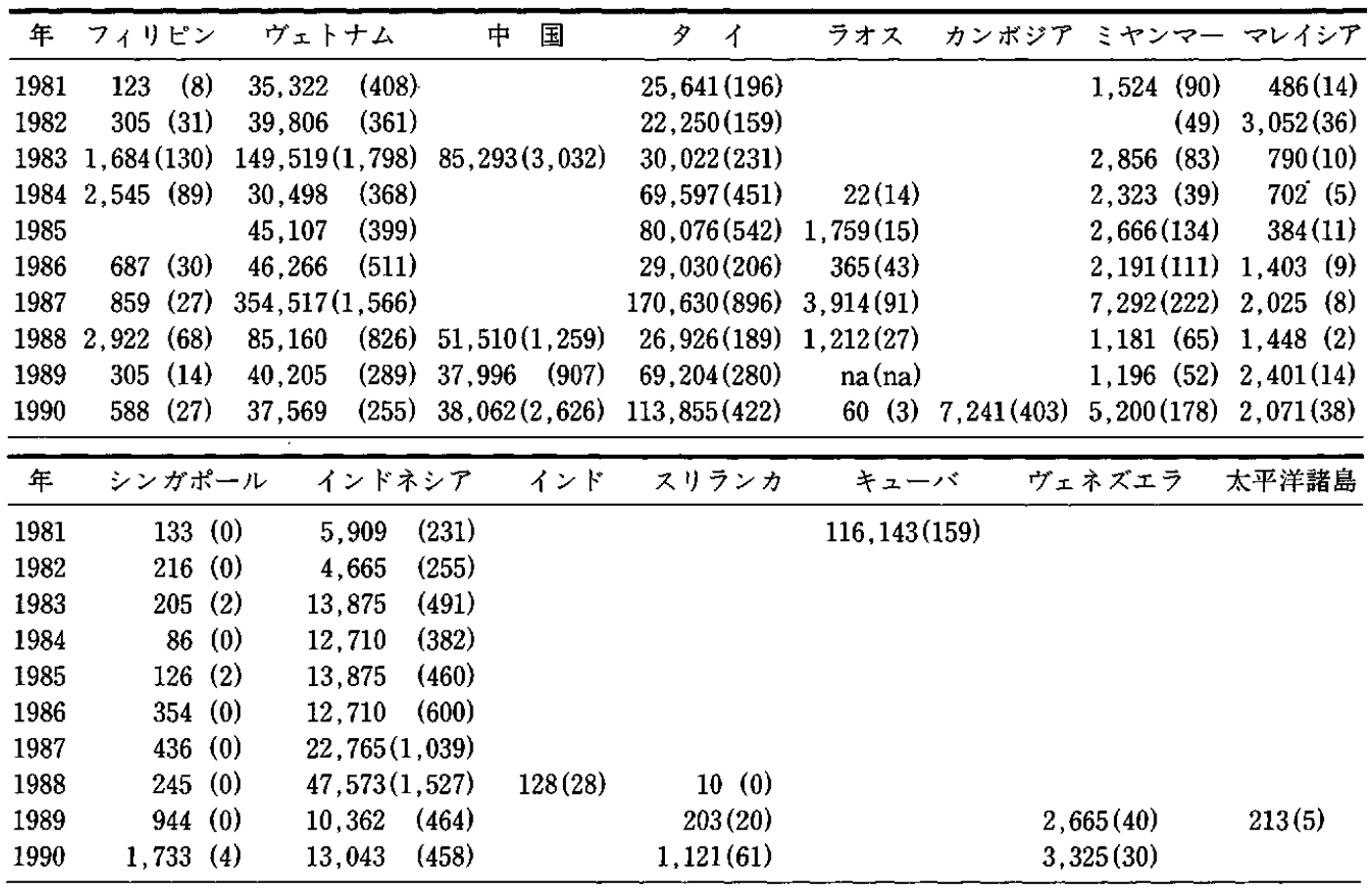

文献14）より改変

表 4 アジア諸国における日本脳炎患者数（死者数）の年次推移

\begin{tabular}{rlrrrrrrrrr}
\hline 年 & \multicolumn{1}{c}{ 中 } & 国 & \multicolumn{1}{c}{ 韓国 } & 日本 & ヴェトナム & \multicolumn{1}{c}{ タ } & \multicolumn{1}{c}{ インド } & ネパール & スリランカ \\
\hline 1981 & 39,985 (na) & $194(\mathrm{na})$ & $23(5)$ & $1,095(298)$ & $1,562(257)$ & $3,894(1,167)$ & $54(16)$ & na & $(0)$ \\
1982 & 31,889 (na) & $1,197(\mathrm{na})$ & $21(4)$ & $2,709(532)$ & $1,504(268)$ & $3,515(1,260)$ & $843(390)$ & na & $(0)$ \\
1983 & $24,260(2,486)$ & $139(15)$ & $32(8)$ & $3,244(600)$ & $2,084(371)$ & $1,716(581)$ & $243(36)$ & na & $(0)$ \\
1984 & 26,259 (na) & na(na) & $27(5)$ & $2,431(407)$ & $1,618(231)$ & $3,321(1,405)$ & $142(45)$ & na & $(0)$ \\
1985 & 29,065 (na) & $0(0)$ & $39(8)$ & $4,935(592)$ & $1,980(267)$ & $2,490(916)$ & $595(146)$ & $441(65)$ \\
1986 & $18,282(1,587)$ & $0(0)$ & $26(3)$ & $2,889(515)$ & $1,723(231)$ & $7,500(2,617)$ & $1,600(420)$ & $336(70)$ \\
1987 & $24,390(2,283)$ & $3(0)$ & $37(7)$ & $3,225(335)$ & $1,711(181)$ & $3,515(1,346)$ & $500(135)$ & $766(138)$ \\
1988 & $25,123(2,106)$ & $1(0)$ & $32(4)$ & $2,724(297)$ & $1,587(\mathrm{na})$ & $6,817(2,407)$ & $1,390(400)$ & $163(26)$ \\
1989 & $17,098(1,100)$ & $1(0)$ & $37(4)$ & na(na) & $1,301(168)$ & $6,400(2,422)$ & $888(227)$ & $293(49)$ \\
1990 & $38,062(2,626)$ & $1(0)$ & $54(8)$ & $916(95)$ & $1,208(125)$ & $1,574(1,291)$ & $365(102)$ & $387(43)$ \\
\hline
\end{tabular}

na*:資料入手できず。文献20) より改変

したヒトが潜伏期間中に移動する頻度が増加した。こ のようなヒトが，ネッタイシマカと感受性個体が存在 する Dengue receptive areaに移動してウイルスを持 ち込むと爆発的な流行を引き起こすことになる。中国 の海南島 ${ }^{29)}$, 南米のブラジル, 南太平洋諸島でのデング ウイルス感染症の流行がその実例である。

\section{2. デング出血靠 (DHF) 発病機檴}

DHF の発病機構に関しては従来からウイルス毒力説 と二次感染説とが対立的に議論されてきた。ウイルス
毒力説は単純明瞭であるが直接の証拠がなかった ${ }^{31)}$ 。最 近重症患者から分離されたデングウイルスは軽症患者 から分離されたデングウイルスに比べてヒトの末梢白 血球でよく增殖し, 後述する抗体による增殖促進を受 けやすい傾向があると主張する論文が発表されたが28), その内容はいまだ説得力が十分とはいえない。

一方の二次感染説は過敏説 ${ }^{32)}$ と免疫增殖説 ${ }^{13,15)}$ に分 かれ，それらを支持するいくつかの事実が存在する。 しかし, 二次感染説の欠点は氷山現象 (Iceberg phenomenon）を説明しにくいことである。免疫増殖促進説を 
唱之る Halstead は水山現象を中和抗体と免疫增殖促 進抗体とのバランスで説明しており ${ }^{13)}$,この考えを支持 する知見がバンコックで行われた prospective な疫学調 查で示している7,21)。

㧈そらく，ウイルス毒力説・二次感染説は二律背反 的ではなく，それぞれ真理の一面を強調していると考 えられる。更に，1981年キューバでの流行では黒人は 白人よりも重症の DHFになり難い事実か観察されてい ることは ${ }^{12)}, \mathrm{DHF}$ 発症に対する何らかの抵抗性遺伝子 がヒトに存在することを示唆している。これらの詳細 な解析は今後の研究課題である。

\section{3. デング対策としてのワクチン開発}

デングワクチンは未だ開発段階で実用化されていな い。デングウイルスが分離されて間もなく開発された 古典的なマウス脳継代による弱毒性ワクチンは米国 FDA (Food and Drug Administration)によって人体用とし て認可されなかった。従って培盖細胞継代よる弱毒デ ングワクチンの開発研究が行われた。米国 Walter Reed 陸軍医学研究所ではサル腎臟培盖細胞を用いてデング

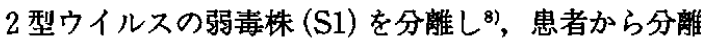
された原株とは異なることをマーカー試験で確認した 後に人体接種実験を行った。その結果, 黄熱ワクチン 接種歴のある七トでは十分量のワクチンを接種すると $100 \%$ の中和抗体産生を示し少なくとも 1 年間は抗体が 持続した。しかし，黄熱ワクチン接種歴のないヒトで は最も大量のワクチンを接種しても中和抗体産生率は $60 \%$ に過ぎず，6力月後には中和抗体保検出限度以下 に低下した ${ }^{33)}$ 。S1株接種による副反応は軽微であった ので, S1株は理想的なワクチンとはいえないが黄熱ワ クチン接種歷があり 2 型デングウイルスに感染する危 険性のある成人には使用できると判定された”。一方， 同様の方法で開発された 1 型と 4 型デングワクチン候 補株は 2 型 S1株同様のマーカー試験結果を示したにも かかわらず人体実験では副反応が強くワクチンとして は不適格と判定され，試験管内のマーカー試験結果は 人体に対する弱毒化の指標として適当でないことも判 明した。最近， 4 型デングウイルスでも人体に対する 弱毒株が得られたと報告されている18,24)。

タイ国マヒドン大学ではイヌ腎細胞培養を継代する ことによって 2 型デングウイルスの弱毒株 PDK53を開 発して人体接種実験を行った。その結果，日本脳炎ウ イルスに对する抗体の有無にかかわらず $100 \%$ デングウ イルス 2 型に对する中和抗体を産生した。ただし日本 脳炎に対して抗体を保有していたヒトの方が抗体を保
有していなかったヒトよりもデングウイルスに对して 高い抗体価を産生した ${ }^{3)}$ 。同様の方法で 1 型と 4 型デン グウイルスの弱毒株が開発され，1，2，4 型を混合 した 3 価ワクチンを接種すると 3 つ型のデングウイ ルスに対して中和抗体が産生されている。一方， 3 型 デングウイルスはイヌ腎細胞では継代できなかったの でサル腎細胞を使用して弱毒化が行われている。4つ の型のデングウイルスに対して弱毒化が得られた時点 で 4 種混合ワクチンの接種実験が行われる予定である。

一方, WHO はバイオテクノロジーを応用したデング ワクチン開発を推進しており，その戦略は(1) 感染防御 抗体の同定，(2) 感染防御抗原の発現，(3) 病原性遺伝 子の同定，(4) 人工弱毒ワクチンの作成，の 4 本柱から 構成されている4)。(1)の目的はほとんど達成され，E夕 ンパクと NS1タンパクがワクチン開発の对象とされた。 (2)の目的に対しては種々の組換え体を用いてEと NS1 タンパクを発現する研究が行われ，発現産物を実験動 物に接種すると中和抗体が産生されマウスモデルでは 感染防御に成功している つかのワクチン候補株とその親株の遺伝子塩基配列を 比較解析して病原性に関与する遺伝子を同定しようと しているが，䙓数の変移が遺伝子の全体に分布してい るので未だ病原性遺伝子が同定されていない。(4)の目 的に対しては, Rice らが黄熱ウイルスの感染性 RNA を転写できる cDNA を構築した手法年をを応用して人工 的弱毒デングワクチンを作成しようというものである。 Rice らと類似の方法で日本腷炎ウイルスに对しても試 験管内で感染性 RNA が合成されたと報告されたが35), 4 型デングウイルスの場合には，大腸菌株を適当に選 択すれば遺伝子全長に相当する cDNA をプラスミドの 形で増殖させることができたと報告され ${ }^{23)}$, 異なるフラ ビウイルスの遺伝子を入れ替えたキメラウイルスも作 成されている5)。しかしながら，このような基礎的研究 結果を実用的な人体用ワクチンに庥用するには今後さ らに数多くの実験を必要とするので, 組み換えデング ワクチンの実用化には今後更に10年を要するであろう。

\section{4. デングウイルス媒介妏の防除}

デングウイルス感染症に対する今一つの防除手段で ある媒介蚊対策は従来から行われてきたがその効果が 永続的でないことが点であり ${ }^{44)}$ ，キューバ以外では成 功していない99。化学殺虫㨈散布によって媒介蚊密度は 一時的に減少するがすぐに Rebound 現象によって蚊の 個体数が増加するので媒介蚊防除は云うはやさしいが 困難な課題である。シンガポールでは強力な中央政府 
の施策としてデング媒介蚁の防除を行い，一時はそれ に成功したと伝えられた。しかしながら最近ネッタイ シマカの House index が $1 \%$ 台に低下したにもかかわ らず再び患者数が增加傾向を示している。この事実は, 媒介蚊対策によってデングウイルスの伝播率が低下し たので自然免疫による感染防御率が低下したことによ ると説明されている。

このような中央政府の施策として強力な媒介蚊对策 を実施する Top-down 方式に代わって，住民参加によ る Primary health careの一環として媒介蚊对策を行 おうとする Bottom-up 方式なるものが提唱されている が10)，現在までその実績が存在しない。

このような状態故にデングウイルス感染症に対寸る 防除対策は現在のところ手詰まり状態であり，何らか の Break-through がなされなければならない。

\section{日本眇炎}

\section{1. 日本成炎の現況}

日本脳炎は高熱・頭痛・意識障害を三主徵候とする 急性脳炎であり，致命率が高く $(25-50 \%)$ ，回復者の 約半数も精神・神経障害を伴う後遺症を残すことから 重要な疾患である。日本脳炎という名称は日本で初め て病原体ウイルスが分離された歴史的事実に由来して いるが，日本脳炎抢よU゙日本脳炎ウイルスは，東アジ アから東南アシアを経て南アジアに至るアジアモンス

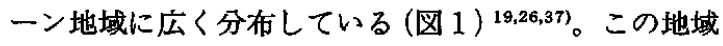
に存在するいくつかの諸国における日本脱炎患者数の 年次変動を表 4 に示している。

日本における1966年以後の患者激減は周知のように 媒介蚊の減少と予防ワクチンの大規模接種に起因して いる。韓国では 1981 年以後急激に患者数が減少し, 1983 年以後は公式認定患者はほとんど皆無と報告され，そ の原因も尒防ワクチンの大規模接種であると云われて いる。中国では10億以上の巨大人口を反映していると はいうものの, 年間 1-2万名以上の患者が発生して いる。中国は独自の不活化ワクチンをハムスタ一腎細 胞培盖を用いて生産しているが未だ需要を満たすには 不十分なので, 弱毒生ワクチンを開発している。WHO 専門家会議において日本製と中国製の不活化ワクチン に共通する国際基準が制定されたが, 弱毒生ワクチン はそれに対する国際基準は未だ制定されておらず，中 国だけで使用されている。ヴェトナムでは1965年には 臨床的に日本脳炎と目される急性脳炎症候群 (Acute encephalitis syndrome=AES）が流行した。その後, 患者数と流行地域は増加・桩大して1970年には患者数
5,000 名に達し, 現在でも年間 1,000 名以上の患者が発 生しており，その $30-50 \%$ は血清診断により日本媨炎 と判定されている。日本脳炎ウイルスは死亡患者の脳 や血液, 媒介蚊, ブタ, 野鳥から分離されている。夕 任も以前から日本脳炎が存在したのであろうが, 1969 年北部チェンマイ地方での流行以後多発するようにな った。当時夕イ国立ウイルス研究所に勤務中の山田毅 博士がタイ国研究者と協力して患者から日本脳炎ウイ ルスを分離し，血清疫学的研究を行った。翌1970年に は米国陸軍医学研究所の研究者らが更に詳細な研究を 実施したが，患者は次第に増加すると共に流行地域も 拡大して, 1979年には夕イ国で2,000名以上のウイルス 性脳炎患者が記録された。血清彰断ではウイルス性脳 炎の約半数は日本脳炎と診断されている。ネパールの 南部インドに接する Terai 平原では1978年に日本脳炎 が大流行し, 数百名の患者が発生した。同年インドで は数千名の患者が記録されており,スリランカでも 1985 年以後年間数百名の日本脳炎患者が発生している。

日本と韓国で日本脳炎患者が激減したのとは对照的 にいくつかのアジア諸国で1960-70年代以後日本脳炎 が多発するようになった原因は未だ十分には解明され ていない。しかし，第二次世界大戦以後における発展 途上国の爆発的人口はまぎれもない事実である。人口 増加は医療の進歩に依存することは言を持たないが, 食料增産・経済発展を必要としている。アジアモンス ーン地域では食料增産は米作のための水田耕地面積の 拡大あるいは二期作の導入，およびタンパク性食料獾 得のための養豚の拡大に連なることは容易に想像でき る。その結果, 日本脳炎媒介蚊の発生源と日本脳炎ウ イルスの增幅動物が共に增加する結果, 日本脳炎患者 が多発することは容易に理解されよう。その実例はス リランカ, インド, ネパール南部で認められている。

\section{2, 日本媨炎防除対策}

日本脳炎の恐ろしさは流行地域の住民は十分承知し ているが，中央政府の感覚は必ずしもそれとは一致し ないこともあったが，最近は日本脳炎防除対策を国家 政策として取り上げる方向にある。現在最も信頼性が あり有効な日本脳炎防除対策は上卜に対する予防ワク チン接種であるが，国内生産が需要を満たしているの は日本と韓国にすぎない。日本のワクチン生産技術は 国際協力事業団の技術援助によってインドとタイ国に, ヴェトナムには WHO 西太平洋支局 (WPRO) の援助 によって，それぞれ技術移転が行われ自国生産を開始 しているが生産量は未だ需要を満たすには程遠い状態 
である。

アジアにおける日本脳炎防除に関して，第一に日本 脳炎防除对策を流行地域の国家政策の一つとして取り 上げる必要がある。その政策に従って各国の条件に則 したウイルス研究室・検查施設が設置されなければな らない。ウイルス学は医科学領域でも最も新しく発展 しつつある分野なのでこの課題は重要であり，日本を 含む先進国の協力が必要であろう。さらに，疾患防除 の観点からは予防ワクチンの接種が最も望ましいこと は上述の通りであり，日本製のワクチンがタイ国 ${ }^{17) や ウ ゙ ~}$ エトナム ${ }^{36)} て ゙ も$ 有効なことは示されている。しかしなが ら現在日本脳炎の流行が問題となっている諸国のほと んどは発展途上国であり，これらの地域において予防 ワクチンの大規模接種を行うには現行ワクチンの価格 と供給量が問題であることはWHO が指摘していると うりである。この問題に対する解決策として組換之DNA 技術を用いた第二世代日本脳炎ワクチンの開発が提唱 されている。この線に沿った研究が行われ，日本脳炎 ウイルスの感染防御抗原を組み換え DNA 技術を用いて 発現させたり ${ }^{25,45)}$, 試験管内で構築した日本脳炎ウイル スの cDNA 分子から感染性 RNA を転写することに成 功している35)。しかし, 上記の事実を考えると，第二世 代ワクチンは現行ワクチンよりも安価で大量供給がで きるばかりでなく, 現行ワクチンに勝とも劣らない安 全性と有效性を備えていることが要求される。

\section{おわりに}

日本脳炎は現在日本では低流行状態が存続しており， 黄熱・デングウイルス感染症も熱带地域への旅行者が 感染する以外には患者発生がないが，世界の繁帯地域 ではこれらの蚊で媒介されるフラビウイルス病が大き な問題となっていることをご理解いただければ幸いで ある。日本が先進国の一つとして国際社会への貢献が 求められている今日, 日本の優れたウイルス学の経験 と技術が疾病对策を通じて近隣諸国住民の健康・福祉 の向上に奇与することができれば，その成果は単に当 該諸国の発展に益するばかりでなく, 翻って日本を含 む先進国の利益にも連なることは云うまでもなからう。 冷戦時代の終幕は相互不信と対立に代わって相互理解 と相互扶助を基調とした共存・共栄の時代の始まりで あり，医学協力はその最たるものであろう。

\section{文㓓}

1) Bancroft, W.H., Scott, R.McN., Eckels, K.H., Hoke, C. H. ,Simms, T.E. , Jesrani, K.D.T.,
Summers, P.L., Dubois, D.R., and Russell, P. K. (1984).Dengue Virus type 2 vaccine: reactogenicity and immunogenicity in soldiers. J.Infect.Dis. 149,1005-1010.

2) Berge, T.O. (ed.) (1972). International Catalogue of Arboviruses Including Certain Other Viruses of Vertebrates. 2nd ed. U.S.Dept. Hlth.Educ. Welf., Publ. Hlth. Serv., Washington, D.C.

3) Bhamaraprvati, N. , Yoksan, S. ,Chayaniyayothin, T. , Angsubphakorn, S., and Bunyaratvej, A . (1987) . Immunization with a live attenuated dengue-2-virus candidate vaccine (16681-PDK 53): clinical immunological and biological responses in adult volunteers. Bull.WHO. 65, 189-195.

4) Brandt,W.E. (1988) . Current approaches to the development of dengue vaccines and related aspects of the molecular biology of flaviviruses. J.Infect. Dis. 157, 1105-1111.

5) Bray, M. , and Lai, C,-L. (1991) . Construction of intertypic chimeric dengue viruses by substitution of structural protein genes. Proc. Natl. Acad.Sci.USA . 88, 10342-10346.

6) Bray, M. ,Zhao, B. , Markoff, L. ,Eckels, K., Chanock, R.M., and Lai,C.-J. (1988). Mice immunized with recombinant vaccinia virus expressing dengue 4 virus structural proteins with or without nonstructural protein NS1 are protected against fatal dengue virus encephalitis. J.Virol. 63, 2853-2856.

7) Burke, D,S., Nisalak, A., and Johnson, D.E. (1988). A prospective study of dengue infection in Bangkok. Am.J.Trop.Med.Hyg. 38,172180.

8) Eckels, K.H. , Brandt, W.E., Harrison, V.E., McCown, J.M., and Russell, P.K. (1976). Isolation of temperature-sensitive dengue-2 virus under conditions suitable for vaccine development. Infect.Immun. 14,1221-1227.

9) Gessa, J.A.A., and Gonzalez, R.F. (1986) . Application of environmental management principles in the program for eradication of Aedes (Stegomyia) aegypti (Linneus, 1762) in the Republic of Guba, 1984. PAHO Bull. 20,186 
-193 .

10) Gubler,D.J. (1989). Aedes Aegypti and Aedes aegypti-borne disease control in the 1990s: top down or bottom up. Am.J.Trop, Med.Hyg. 40,571-578.

11) Guzaman, M.G. , Kouri, G.P. , Bravo, J. ,Calunga, B.M., soler, M. , Vazquez, S. , and Venereo,C. (1984). Dengue haemorrhagic fever in Cuba. I. Serological confirmation of clinical diagnosis. Trans.R.Soc.Trop.Med.Hyg. 78, 235-238.

12) Guzman, M.G., Kouri, G. P., Bravo, J., Soler, M. ,Vazquez, S. , and Morier,L. (1990). Dengue hemorrhagic fever in Cuba,1981: a retrospective seroepidemilogical study. Am.J. Trop.Med.Hyg. 42,179-184.

13) Halstead, S. B. (1988) . Pathogenesis of dengue: challenge to molecular biology. Science 239, 476-481.

14) Halstead,S.B. (1992) . The XXth century dengue pandemic: need for surveillance and research. Wld. Hlth.Statistics Quart. 45,292298.

15) Halstead,S. B. , and O'Rouke, E.J. (1976) . antibody-enhanced dengue virus infection in primate leukocytes. Nature (London) 265,739741.

16) Hammon, W.McD., Rudnick, A., and Sather, G.E. (1960). Viruses associated with epidemic hemorrhagic fevers of the Philippines and Thailand. Science 131,1102-1103.

17) Hoke,C.H., Nisalak, A., Sangkawipha, N., Jatanasen, S. ,Laorakapongse, T . Innis, B. L., Kotchasenee, A. , Gingrich, J. B. , Latendresse, J. ,Fukai, K., and Burke,D.S. (1988) . Protection against Japanese encephalitis by inactivated vaccines. N.Engl.J.Med. 31,608-614.

18) Hoke, C. H. , Jr ., Malinoski, F. J., Eckels, K. H. , Scott, R. M. Dubois, D.R., Summers, P.L. Simms, T. , Burrous, J. , Hasty, S. W . , and Bancroft, W.H. (1990). Preparation of an attenuated dengue 4 (341750 CARIB) virus caccine. II. Safety and immunogenicity in humans. Am.J. Trop.Med.Hyg. 43, 219-226.

19) Igarashi, A. (1992). Japanese Encephalitis.
Virus, Infection and Control. pp309-342. In E. Kurstak (ed.). Control of Virus Diseases, marcel Dekker, New York.

20) Igarashi, A. (1992). Epidemiology and control of Japanese encephalitis. Wld. Hlth.Statist. Quart. 45, 299-305.

21) Kiklis, S.C. , Nisalak, A. ,Brandt, W.E., Wahl, L., and Burke,D.S. (1989). Antibody dependent enhancement of dengue virus growth in human monocytes as a risk factor for dengue hemorrhagic fever. Am.J.Trop.Med.Hyg. 40, 444-451.

22）国連連合統計局 $(1983 / 1984)$ ，世界統計年鑑. 原書 房. 東京.

23) Lai, C.- J. ,Zhao, B., Hori, H., and Bray, M. (1991). Infectious RNA transcribed from stably cloned full-length cDNA of dengue type 4 virus. Proc. Natl.Acad.Sci. USA. 88,51395143.

24) Marchette, N. J. , Dubois, D. R. , Larson, L.K., Summers, P.L., Kraiselburd, E.G. , Gubler, D. J., and Eckels, K.H. (1990) . Preparation of an attenuated dengue 4 (341750 CARIB) virus vaccine.I. Pre-clinical studies. Am.J.Trop. Med. Hyg. 43,212-218.

25) Matsuura, Y., Miyamcto, M., Sato, T., Morita, C. , and Yasui, K. (1989). Characterization of Japanese encephalitis virus envelope protein expressed by recombinant baculoviruses. Virology 173,674-682.

26) Miles, J.A.R. (1960) . Epidemiology of arthropod-borne encephalitides. Bull. WHO. 22,339-371.

27) Monath, T.P. (1986) . Pathology of the falviviruses. pp375-440.In S.Schlesinger and M.J. Schlesinger (eds.). The Togaviridae and Flaviviridae. The Viruses (Series eds. H. Fraenkel-Conrat and R.R.Wagner). Plenum Press, Ner York.

28) Morens, D.M. , Marchette, N. J. ,Chu, M.- C, and Halstead,S.B. (1991). Grown of dengue type 2 virus isolates in human peripheral blood leukocytes correlates with severe and mild dengue disease. Am.J.Trop.Med.Hyg. 45,644 -651 . 
29) Qiu, F.X., Chen, Q.- Q.- Y.,Chen, W.- Z., Zhao,Z.-G., and Zhao,B.-W. (1991). The first epidemic of dengue hemorrhagic fever in the People's Republic of China. Am.J.Trop. Med.Hyg. 44,364-370.

30) Rice, C.M., Grakouri, A., Galler, R., and Chambers, T.J. (1989) . Transcription of infectious yellow fever RNA from full-length cDNA templates produced by in vitro ligation. New Biol. 1,285-296.

31) Rosen, L. (1977). The emperor's new clothes revisited, or reflections on the pathogenesis of dengue hemerrhagic fever. Am.J.Trop.Med. Hyg. 26, 337-343.

32) Russell, P.K., Brandt, W.E. (1973). Immunopathological processes and viral antigens associated with sequential dengue virus infection. pp263-277. In Pollard, M. (ed.) . Persistent Virus Infections.Perspectives in Virology Vol.8.

33) Scott, R.M., Eckels, K.H. , Bancroft, W.H., Summers, P.L., McCown, J.M. Anderson, J. H., and Russell, P.K. (1983). Dengue 2 vaccine: dose response in volunteers in relation to yellow fever status. J.Infect.Dis. 148,10551060.

34) Shope,R.E. (1980). Medical significance of togaviruses: and overview of disease caused by togaviruses in man and in domestic and wild vertebrate animals. pp47-82. In R.W.Schlesinger (ed.). The Togaviruses, Biology, Structure, Replication. Academic press, New York.

35) Sumiyoshi, H., Hoke,C.H., and Trent,D.W. (1992). Infectious Japanese encephalitis virus RNA can be synthesized from in vitro-ligated cDNA templates. J. Virol.66,5425-5432.

36) Tien, T.V., Nguyen, H.T., Man, V.S., Nga, P.T., and Igarashi, A. (1991). Prevention of Japanese encephalitis (JE) by "BIKEN" vaccine and epidemiological survey on JE in Dong
Anh District, Hanoi, Vietnam. Trop.Med. 33, 83-91.

37) Umenai, T., Krzysko, R. , Bektimirov, A. , and Assaad, F.A. (1985). Japanese encephalitis: current worldwide status. Bull. WHO. 63:625$631,1985$.

38) Wengler,G. (1991). Flaviviridae. pp223-233. In R.I.B.Francki,C.M.Fauquet, D.L.Knudson,F.Brown (eds.). Classification and nomenclature of viruses. Arch. Virol.Suppl.2.

39) World Health Organization (1983). Yellow fever in 1982. Wkly. Epidem. Rec. 58,313-317.

40) World Health Organization (1984). Yellow fever in 1983. Wkly. Epidem. Rec. 59,329-335.

41) World Health Organization (1986). Yellow fever in 1986. Wkly. Epidem. Rec. 61,377-380.

42) World Health Organization (1989). Yellow fever in 1987. Wkly.Epidem. Rec. 64,37-43.

43) World Health Organization (1992). Yellow fever in 1989. and 1990. Wkly. Epidem. Rec. 67, 245-251.

44) World Health Organization, Geneva (1986) . Dengue haemorrhagic fever: diagnosis, treatment and control.

45) Yasuda, A., Kimura-kuroda, J., Ogimoto, M., Miyamoto,M., Sata, T., Sato, T., Takamura, C.,Kurata, T.,Kojima, A., and Yasui, K. (1990). Induction of protective immunity in animals vaccinated with recombinant vaccinia that express PreM and E glycoproteins of Japanese encephalitis virus. J.Virol. 64 ,27882795.

46) Zhang, Y. - M., Hayes, E.P., McCarty, T.C., Dubois, D. R. ,Summers, P.L., Eckels, K. H. , Chanock, R.M. , and Lai, C.-J. (1988) .Immunization of mice with dengue structural proteins and nonstructural protein NS1 expressed by baculovirus recombinants induces resistance to dengue encephalitis. J. Virol. 62,3027-3031. 